\title{
Brave New Words: The Complexities and \\ Possibilities of an "Indigenous" Identity \\ in French Polynesia and New Caledonia
}

Natacha Gagné

\begin{abstract}
The adoption of the United Nations (UN) Declaration on the Rights of Indigenous Peoples in 2007 was seen by many people throughout the world (including a number of anthropologists ${ }^{1}$ ) as a hopeful step in this postcolonial world in the making. And yet, as this article attempts to show, in the cases of French Polynesia and New Caledonia, the category "indigenous" is problematic and full of complexities.

In French Polynesia and New Caledonia, the "indigenous strategy"-in reference to the world indigenous movement and $\mathrm{UN}$ indigenous rights instruments-is a relatively new one in the struggle to recover sovereignty. ${ }^{2}$ Individuals and volunteer associations only began to explore the possibilities of this strategy in the mid-I990s, and it continues to hold a marginal place in the political field of the French territories, particularly in French Polynesia.

As Florence, a Tahitian woman in her late fifties, stated, "People do not recognize themselves as an indigenous people, do not want to be an indigenous people ... since indigenous means subhuman" (pers comm, Tahiti, May 20II). This quotation clearly shows the negative connotation that the category "indigenous" can carry in the French territories of Oceania. A large number of Mā'ohi people have no desire to use the label for themselves, and, unlike people in many other parts of the world, do not see the "indigenous strategy" as useful in the struggle for decolonization or sovereignty. As for the Kanak people, the situation is slowly changing.

How can we explain this reluctance, in the context of the progress made in recent years by indigenous peoples around the world in terms of recognition? This study explores the impact that the international indigenous peoples' movement and the adoption of the UN Declaration on the Rights
\end{abstract}

The Contemporary Pacific, Volume 27, Number 2, 371-402

(C) 2015 by University of Hawai' $i$ Press 
of Indigenous Peoples have had on strategies of decolonization or sovereignty in French Polynesia and New Caledonia. I consider how indigeneity and indigenous rights are understood and enacted locally, drawing on local voices and actions within a local and national context. What does being an "indigenous people" mean? What does the "indigenous strategy" achieve, or fail to achieve, for locals? In what contexts and for what reasons is the "indigenous strategy" appealing? For whom? While this article is intended to be comparative, my main emphasis is on French Polynesia since others have already discussed how the "indigenous strategy" has been used in New Caledonia in recent years (among them Demmer 2007; Graff 20I2; Horowitz 2004, 2009, 20IO, 20I2; Monnerie 2005; Trépied 20I2a).

First, I examine how the political field has historically been structured in French Polynesia and New Caledonia. As we will see, local and national contexts are configured in an extremely different fashion than in the anglophone Pacific, the rest of the former British Empire, and Latin America, where people first came together around the category "indigenous peoples" from the I96os onward. These differences will continue to come to light throughout this article.

\section{Some Elements of the Political Backgrounds}

In current French public debates about a postcolonial France in the making, the situations of the Mā'ohi of French Polynesia and the Kanak of New Caledonia-along with those of the Amerindians of Guyana, the Mahorais of Mayotte, and the Pacific Islanders of Wallis and Futuna-are vastly overlooked. As Benoît Trépied has pointed out, "There is an important blind spot in all these discussions of the French (post)colonial context: the distinct situation of formerly colonized native subjects who remained under French sovereignty even after the wave of independence that began in the I960s" (2012b). This is also true of academic scholarship, despite the "staggering surge in publication and debate" (Stoler 20II, I23) on French colonial history in France over the last decade. Trépied added that these populations "occupy a paradoxical position—at once marginal and central-in the French postcolonial debate. They are marginal insofar as their small numbers in the metropole, compared to the children of African immigrants and descendants of slaves originating from overseas territories, contribute directly to their social and cultural invisibility at the national level. Yet they are central because their historic trajectories remind us so 
forcefully of the eminently colonial matrix of the category of 'overseas' [in reference to the French 'overseas territories'], which makes the 'indigenous question' very relevant in today's France” (20I2b).

On I 8 May 20I3, however, a decision of the UN General Assembly placed this French colonial legacy under a bright spotlight: a consensus resolution, tabled by three Pacific Island states (Nauru, Tuvalu, and Solomon Islands), was adopted, which added French Polynesia back to the UN list of territories that should be decolonized (see Gonschor 20I3). ${ }^{4}$ With this resolution, the UN General Assembly affirmed "the inalienable right of the people of French Polynesia to self-determination and independence" under the UN Charter and asked France to "facilitate rapid progress... towards a self-determination process." The re-listing of French Polynesia on the UN decolonization list has been championed by Tahitians Oscar Temaru, president of the independentist party Tavini Huiraatira and fivetime president of French Polynesia between 2004 and 2013 (EPF 20I3), and Richard Tuheiava, a member of the French Senate representing French Polynesia between 2008 and 20I 4 and deputy member of the French Polynesian Assembly since spring 20I3 (also a member of the Tavini Huiraatira; see Massau 20I I for a discussion of his position on this issue).

In May 20I3, the French minister of foreign affairs reacted promptly and vehemently to the General Assembly's resolution, taken in a session that was boycotted by France's UN ambassador. In the minister's words, the resolution "constitutes complete interference" and goes against the democratic choices of French Polynesians. In the general elections on 2 I April and 5 May 2013, President Temaru was defeated and the electors gave a "clear majority to the representatives more favorable to the actual autonomy status" (FD 2013), including the president of the autonomous party (Tahoera'a Huiraatira), Gaston Flosse. ${ }^{5}$

The newly elected president of French Polynesia has not missed a chance to preempt a debate on self-determination in the French territory. At the 44th Pacific Islands Forum (held in Majuro in the Marshall Islands from 3 to 6 September 2013), Flosse reminded the assembled leaders of the resolution approved by the French Polynesian Assembly (46 votes for and I I against) on I7 August 20I3. The resolution states: "The Assembly of French Polynesia recalls the right of French Polynesia to live within the statutory framework that French Polynesia chose, that is Autonomy within the French Republic" (see Garot 2013).

Although the issue is part of an ongoing debate on the local scene, the public debate around it was short-lived in metropolitan France. 
As for New Caledonia, it has been back on the UN list since I986 (Mohamed-Gaillard 2008; Regnault 20I3). Both French territories are thus now on the agenda of the Special Committee on the Situation with regard to the Implementation of the Declaration on the Granting of Independence of Colonial Countries and Peoples (also known as the Special Committee on Decolonization or C-24). The Special Committee was established in I96I by the UN General Assembly (Resolution I5I4 [XV] of I4 December 1960) in a historical and political context entirely different from today: the context of full decolonization and independence for many colonies in the aftermath of World War II (for historical details, see Regnault 20I3; Gonschor 2013).

France took formal possession of New Caledonia in 1853 and it became a penal and settler colony. The New Caledonian population today is composed of various ethnic groups. Those who identify as Kanak, the descendants of the original population, account for 40.3 percent of the population; those who identify as European, 29.2 percent; those who identify as Wallisians and Futunians, 8.7 percent; and those who identify as métis or who say they belong to many "communities," 8.3 percent (ISEE 2009). ${ }^{6}$ Historically, the watchword for Kanak leaders of what started in 1979 as the Front Indépendantiste (FI, Independentist Front) and then in 1984 became the Front de Libération Nationale Kanak et Socialiste (FLnKs, Kanak Socialist Front for National Liberation) has been socialist Kanak independence. This notion has received strong electoral support from Kanak voters-between 70 percent and 80 percent of their vote (Soriano 200I). The emphasis has been on full sovereignty, following the model developed during the first wave of decolonization in Africa and Asia and in the young states of Fiji, Papua New Guinea, and Vanuatu, which obtained independence in 1970, 1975, and I980, respectively. New Caledonia is a society marked by diverse forms of segregation-for example, the Kanak population has experienced the indigénat regime (repealed in I946; see Merle 2004; Muckle 20I2) and a policy of cantonnement, the practice of confining the Kanak population to reserves. Local politics here has been characterized by a sharp opposition between two camps: independentists on one side and loyalists-loyal defenders of the French Republic-on the other. The political divide tends to follow racial or ethnic lines even though in practice the reality has always been far more complex, and there has always been a "reliable Kanak 'loyalist' minority" (Trépied 20I 2a, 20I3).

The violent uprisings of the I980s known as "les Événements" (the Events) led to two agreements: the Matignon Accords in I988 and the 
Nouméa Accord in I 998. ${ }^{7}$ Since then the French territory has been involved in an ongoing process of "decolonization," the term used in the Nouméa Accord. The originality of this accord lies in the fact that it laid out in advance (and irreversibly) the step-by-step transfers of state powers to the New Caledonian local government. This process could lead, at term, to full independence after a referendum on self-determination, scheduled to take place sometime between 2014 and 2018 . In view of the political divide mentioned above and the light demographic weight of the Kanak population, however, this outcome seems more and more unlikely. In fact, now that a wide array of state powers have already been transferred to the New Caledonian government, numerous possibilities for the form of the destin commun (common destiny) of New Caledonian people are being explored, offering various degrees of autonomy. The country stands at a historic crossroads.

The history of French Polynesia is quite different. Between I 842 and I 880, parts of what is now French Polynesian territory were declared a French protectorate. France was in power but left a measure of autonomy to the indigenous chiefs in certain areas. In contrast to New Caledonia, French Polynesia has not suffered settler colonialism, and some members of the Polynesian population-those of Pomare's kingdomwere given the status of citizen when it formally became a colony at the I 880 annexation, even though discrimination was soon reintroduced in dealing with these citoyens indigènes (indigenous citizens) (Trémon 20I3). France retained significant authority and even tightened its control over the territory after the Second World War, particularly during the period that saw the installation of the Centre d'Expérimentation du Pacifique (CEP, Pacific Experimentation Center) and the nuclear bomb tests, which started in I966 (see Gonschor 2013). But since the end of these tests in 1996, France has gradually withdrawn from French Polynesia, progressively granting the territory more autonomy and reducing money transfers. Until the end of the I970s, there was a split among the population of Polynesian origin-which makes up more than 80 percent of the population ${ }^{8}$ - between those who favored direct administration by France and those who demanded more autonomy. The new status of autonomie de gestion (literally, autonomy of management) granted by France in 1977 opened the door for the creation of yet another division between "those autonomists who hoped to remain within the constitutional framework of the French Republic while disposing of a system of greatly decentralized power and the 'independentists' who advocate 
total sovereignty" (Al Wardi 2010, I 40; see also Al Wardi 2009; Trémon 2006).

In French Polynesia, the opposition between pro-independence and pro-autonomy stances has been personified by the two metua (fathers), Oscar Temaru and Gaston Flosse, for nearly half a century. I was in the field in July 20I3, shortly after Flosse's re-election. ${ }^{9}$ People were resigned, and I repeatedly heard comments similar to the following: "There is no alternative as long as the old lion [Flosse] and his longtime rival are there. They don't leave any space for young leaders to assert themselves and for visions of alternative futures to emerge."

Beyond the traditional political parties and channels, however, a new way of framing the claims for increased autonomy and the restoration of sovereignty has been explored by segments of the Kanak and Tahitian populations in recent years. Volunteer associations have been at the forefront of advocacy for indigenous rights. These people affirm their identity as autochtones (indigenous people), ${ }^{10}$ and some of them insist on their special status or rights in reference to the world indigenous movement and the UN Declaration on the Rights of Indigenous Peoples.

\section{PaCific Is landers and the World Indigenous Movement:} The Beginning

Māori leaders from New Zealand and Aborigine leaders from Australia, along with Amerindians and Inuit leaders, were the first to bring their case to international attention and to appeal (in the I970s) to the United Nations for the protection of their rights as "indigenous peoples" under international law (Minde 1996; Niezen 2003). Representatives of other peoples from settler states who missed the opportunities of the first wave of decolonization in the r960s, such as Hawaiians and the Torres Strait Islanders of Australia, who also define themselves as indigenous, rapidly joined their ranks.

Throughout the years, these leaders made themselves heard, with the support of human rights activists, organizations such as churches and sympathetic nonindigenous nongovernmental organizations, as well as certain states (see Bellier 2003; Morin 2009). This led to the creation of the UN Working Group on Indigenous Populations (WGIP) in 1982, the UN Permanent Forum on Indigenous Issues in 2000, and the adoption of the declaration in 2007. This last event received fairly significant public attention throughout the world, including from the main (predominantly 
anglophone) media in the South Pacific. The declaration was also featured widely on the Internet.

Pacific Islanders from the French territories came late and only irregularly to the UN meetings about indigenous rights. The International Year of the World's Indigenous People, I993, was the first year that two Kanak representatives, who were also members of FLNKS, participated in a WGIP meeting (Morin 2008). Locally, I993 was also the founding year of the Association pour la Célébration de l'Année du Peuple Indigène en Kanaky (ACAPIK, Association for the Celebration of the Year of the Indigenous People in Kanaky), which in 1995 became the Conseil National des Droits du Peuple Autochtone (CNDPA, National Council for the Rights of Indigenous People) (Demmer 2007; Graff 20I2; Monnerie 2005). Stéphanie Graff linked this early exploration of the "indigenous strategy" to divisions among Kanak independentists following the signing of the Matignon Accords (20I 2, 75). Denis Monnerie emphasized the local impact of UN indigenous rights activities on local Kanak activism in the I990s and drew attention to the change of vocabulary used to speak about the Kanak people: celebrations and claims that were first framed around the peuple indigène were reframed using the term peuples autochtones $(2005,20)$. As I have shown in the case of the Māori of New Zealand (Gagné 20II), this kind of vocabulary shift has become more widespread as the world indigenous peoples' movement makes gains and attracts the attention of the media and academics. ${ }^{11}$ However, as mentioned by Graff (2012, 68), up until $200 \mathrm{I}$ - that is, until the UN meetings concerning indigenous peoples' rights came to New York with the creation of the Permanent Forum on Indigenous Issues ${ }^{12}$ - the presence of Kanak representatives was only sporadic. The Nouméa Accord of 1998 (which has no equivalent in the Polynesian case) has been instrumental in catalyzing "indigenous" politics, as shown later in this article.

Like their Kanak counterparts, French Polynesian people came late to indigenous rights meetings and only irregularly. Françoise Morin traced the first attendance to the World Conference on Human Rights, held in I 993 in Vienna (2008). The conference, which took place during the International Year of the World's Indigenous People, recommended that the General Assembly proclaim an international decade of the world's indigenous peoples. Gabriel Tetiarahi, a representative of the Ligue Polynésienne Indépendante des Droits de l'Homme (the Polynesian Independent League of Human Rights)—also called Te Hui Tiama-attended the conference and was asked to give the inaugural speech on indigenous peoples' rights 
(LDT 2OI3). This first experience led to his attendance at the wGIP the following year (Morin 2008). Tetiarahi was the representative of Hiti Tau, ${ }^{13}$ le Conseil National du Pays Maohi (National Council of the Maohi Country), a Tahiti-based association that he founded in $\mathrm{I} 992$ and that is part of the regional network Pacific Islands Association of Non-Governmental Organisations (PIANGO).

Here is an excerpt from Tetiarahi's statement before the UN wGIP in I995:

Indigenous Peoples of the Pacific firmly refuse to suffer the consequences of a State's need to exteriorize its anguish.... "The earth is our mother," say Indigenous Peoples who all agree on this essential idea.... In the framework of the arms race between major powers, our Shoshonee brothers from the Nevada also suffered from the fundamentally counter-nature of nuclear testing and its destructive effects (6ro of them). Their lands, like in Moruroa, have been ravaged by enormous holes created in the Earth, some of it approximates the size of football fields. Other Indigenous Peoples and their environment are directly being threatened by continuous exposure to radioactivity: Haudenosaunee (six Iroquois Nations of North America) are exposed to radioactive waste left over from the Manhattan project; Inuit in Alaska; Indigenous Peoples in Australia, etc. (Hiti Tau I995)

What is particularly interesting is how this Mā'ohi representative emphasized the strong bonds between his people and the indigenous peoples of the United States and Australia, stressing their common link to the land, to Mother Earth, as well as their common suffering and threat by the great powers' arms race. This has been typical of the world indigenous movement from the start. The frustration engendered by the inability of indigenous peoples to obtain justice from their own national governments has led self-defined indigenous peoples to look beyond their national borders and establish commonalities and international solidarity networks with other indigenous groups, as well as nonindigenous parties who are sensitive to the indigenous cause (Gagné 20I2). These networks have allowed them to use international forums, especially through the UN system, to air their grievances and demands. As Tetiarahi stated recently, "The UN is first and foremost a platform to assert our rights" (LDT 2OI3). According to my understanding, he saw the indigenous rights meetings as being only one of these platforms. Over the years, he has participated in a number of international, trans-Pacific, and European forums and organizations, working on sustainable development, "fighting against nuclear colonial- 
ism, nuclear racism, and nuclear terrorism in the South Pacific" (Peace Boat website 2008; see also LDT 20I3) and calling for self-determination or full sovereignty for Mā'ohi.

In the mid to late 2000s, Mareva Neti de Montluc also attended UN indigenous rights meetings; more specifically, she attended the UN Permanent Forum on Indigenous Issues (UNPFII). The UNPFII has held yearly sessions at the UN headquarters in New York since 2002. To my knowledge, she and Gabriel Tetiarahi are the only two Tahitians to have attended those meetings to date. De Montluc participated in at least three of the UNPFII sessions, as a representative of different local associations, and spoke out on three particular issues: (I) in 2007, she spoke about the nineteenth-century "treaties" that bind France and Tahitian chiefs; (2) in 2008 , as a representative of Hiti Tau (the same association that Tetiarahi represented a decade earlier), she addressed an issue dear to her predecessor-nuclear testing and its effect on the southern Pacific archipelagos and their populations-and asked for the nuclear powers to take responsibility for the harmful effects of their actions; and (3) in 20I0, she spoke on French Polynesia's right to self-determination (UN 2007, 2008, 2010).

In 2008, de Montluc was elected (along with her Kanak counterpart Jean-Yves M'Bouéri) to the management board of the Coordination Autochtone Francophone (CAF, Indigenous Francophone Coordination) as a representative for the Pacific region. In the 2000s, the French branch of the International World Group for Indigenous Affairs (IWGIA)-the Groupe International de Travail pour les Peuples Autochtones (GITPA)was instrumental in the creation and founding of the CAF, whose objectives were first set in 2004 during the third session of the UNPFII (GITPA 2009). Members of the GITPA board of directors supported and even helped secure travel funding for individuals such as de Montluc or Sarimin Boengkih (a Kanak representative who attended CAF meetings) in their participation in indigenous forums. ${ }^{14}$

Having examined these instances (through a media analysis, informal discussions, and semi-directed interviews with people in the field since 2005), I found it clear that the presence of Mā'ohi and Kanak voices at UN indigenous rights forums was made possible mainly through individual initiative and sometimes with the support of foreign nongovernmental organizations. What is striking is that beyond the small volunteer associations they represent at the United Nations, their work as representatives has remained mostly unknown on the local scale, and they did not make any particular effort to inform the population about the UN debates and 
possibilities concerning indigenous issues until 2002 in the case of New Caledonia and until after 20 Io in the case of French Polynesia. Not only is their action invisible, but, as novelist Chantal Spitz stated in an article in Littérama'ohi (in a special issue on indigeneity and indigenous peoples), "The [adoption] of the Declaration on the Rights of Indigenous Peoples by the UN General Assembly on I3 September 2007 almost went unnoticed in our country [French Polynesia] although it had been celebrated by the indigenous peoples of the world" (2OII, 94). ${ }^{15}$ This is also true in New Caledonia. How do we explain this situation?

Vanina, a research participant who sees potential benefits for her people in the UN rights of indigenous peoples, explained why the indigenous rights strategy has not been taken up by people in French Polynesia: "The notion of 'indigenous,' from the French mould, is something that is.... Some view it as a pejorative word. It's as if for us, with regard to our own identity ... certain people have not quite got to the heart of what they find so shocking in this word" (pers comm, Tahiti, May 2007).

As noted earlier, for many people in French Polynesia and New Caledonia, "indigenous means subhuman" (Florence, pers comm, Tahiti, May 20II). Indeed, it means being a second-class citizen-it refers back to the inferior legal status and restricted rights of the indigènes, the French native subjects, in comparison to the full rights and status of the citizens of the French colonial empire from I887 to 1946. And this conception prevails because of the symbolic and historical importance of the category indigènes (Trépied and Guyon 2013) and in spite of the exceptional situation of segments of the French Polynesian population, as mentioned earlier. It is strengthened when they consider the living conditions and extreme marginalization of some who identify as indigenous today, such as certain aboriginal communities in Australia and Canada. As some people in Tahiti told me, they cannot identify with these marginalized communities. "We call it pride!" said Florence (pers comm, Tahiti, May 20I I). The facts that Mā'ohi people form the large majority of the French Polynesian population, and that the autonomy status gives their local governments a large measure of autonomy in many domains within France, certainly account in part for this. Florence even spoke of a certain arrogance of her people that often prevents them from collaborating with other Pacific Island peoples on diverse issues.

The poet Isidore Hiro (brother of the late poet and playwright Henri Hiro, who was a key player in the cultural renaissance from the I970s 
onward that embraced Mā'ohi identity and values) spoke to the ambiguity of the word autochtones (indigenous) for Tahitians:

As far as I can remember, it was at the end of the I980s that I heard the word "autochtone" for the first time. What strikes me is how its usage has spread today. At the time, we could no longer understand who we were exactly, where we were and how we could locate ourselves in relation to this new expression: "autochtone." Who was this person that we call "autochtone"? ... As I understood it, we were not Tahitians anymore, we were not Paumotu, we were not Mangarevians, or inhabitants of the Austral Islands, neither Maupiti, neither other peoples from the Leeward islands, neither Maiào, neither "Mooreaneans"-it meant that we were not Maòhi anymore, but rather autochtones, people from this country. ... But who? ... Where are they from? ... Who are their parents? .. . All these questions have no importance, they were born in this country, so they are from this country. There is nothing to question, we shouldn't try to understand, that's it ... Can we trust this? (20 I I, 37; ellipses in the French original)

Clearly, Hiro is very suspicious of the notion of an indigenous identity. For him, its ambiguity lies in the fact that it could be used to identify two categories of people: those he calls les autochtones natifs (20II, 38)-an expression that, according to him, refers to anyone born in the country, whether or not one's parents or ancestors are from there-and those he calls autochtones de souche (20II, 38), an expression which, for him, refers to the first or original inhabitants of the country-that is, members of the Mā'ohi ethnic group. In the first case, "one is born in this country, he has lived here," and "one's parents and ancestors came from elsewhere," and, in the second case, "one has a visceral connection with the land and one's ancestors" (Hiro 20I I, 39). This distinction seems very important to him and, as we can see, has important political implications.

I believe that the key to understanding this distinction is to be found in the "French mould," as suggested by Vanina above. More specifically, it can be found in the French conception of citizenship and the public debates that surround it: French citizenship is founded upon the "right of birthplace" (jus soli). Being a citizen of the French Republic thus means being a member of a political community, which has no ethnic foundation and has nothing to do with ancestry and a "blood right" (jus sanguinis) (see, eg, Weil 2008). Being a French citizen involves a sense of being autochtone to France. ${ }^{16}$ The idea is also perpetuated by French mainlanders who have 
migrated to a French overseas territory, as well as by their children who were born in the overseas territories, to insist on their right to be there and their legitimacy as citizens of that territory. We sometimes hear such arguments in French Polynesia-to justify titles to land, for instance, or participation in local life and politics, but also to insist on their rights and those of their children to stay in the territory if it achieves independence as a sovereign state. The same has often happened in New Caledonia as well. Arguments of this kind arose around the sensitive issue of the freezing of the electorate for the territorial elections of 2009 and 20I4 as well as the forthcoming referendum on self-determination, a cornerstone of the Nouméa Accord of 1998 (Chappell 2007). ${ }^{17}$ In my opinion, this is why we see a need for Isidore Hiro to create two categories of autochtones.

What is also striking in the quotation from Hiro above is that he is dubious about the category autochtone because it comes from overseas. This echoes many comments I heard while in the field in Tahiti. Once again, something is imposed from outside, like so many appellations that arise from the colonial history such as "French Polynesians" or simply "Polynesians" (see Saura 2008). The category autochtone is also seen as problematic because it is foreign to their language and too abstract: according to Hiro, something about their self-definition is lost with it. As he said in a recent interview: "I am born in Mo'orea, my umbilical cord is on Mo'orea island, my placenta is on Mo'orea, I myself am not a Tahitian, I am a 'Mo'orea-nian"” (Tahiti Infos 2013). And it is as a "Mo'orea-nian" that he belongs to the Mā'ohi people. It seems to me, therefore, that selfidentifying as autochtones consists, for Hiro, of erasing all particularities: those related to his island of origin and those linked to his national identity.

On the complexity of the term, Spitz added: "Still today, the notion of 'autochtonie' remains vague and unclear for a broad segment of society. It is as vague and confused as the meaning given to the word Mā'ohi. Even worse, autochtonie is often presented as meaning exclusion, communitarianism [in French communautarisme, used in this context to denote ethnic isolationism or sectarianism] or independence" (2011, 98). Knowing that for some segments of the population of French Polynesia (and New Caledonia) independence is associated with political uncertainty, poverty, racism, exclusion, and even civil unrest, indigeneity suffers from a negative public perception. As for the word $M \bar{a}^{\prime}$ ohi and Mā'ohi identity, they have been the spearhead of the Tahitian movement of cultural renaissance since the end of the I970s (Saura 2004, 2008). For twenty years, people 
have agreed with the definition given by one of its leaders, Duro Raapoto: "Maohi is the exact opposite of hutu painu (seed adrift). It is generally defined in the following way: common, indigenous-that is, not foreign" (I978, II 5, quoted in Saura 2008, I2I). In the last decade, however, the word has been the subject of sometimes fierce debate about its etymology, precise meaning, local (de)anchoring, Tahiticentrism, and appropriate usage in reference to human beings (see Saura 2008, I33-I 52 for a summary). This speaks volumes about identity politics in French Polynesia and political positioning about, among other things, the future of the territory. For some, the word has lost its original appeal and potential to mobilize people because of these controversies: "[Mā'ohi] will never be a word on which everybody will agree. Never! Then maybe we should not use it anymore.... we have to find an alternative!" (Florence, pers comm, May 20I I). For Florence, the word autochtones (indigenous) might be such an alternative-one that could open new possibilities and unite her people.

I will turn now to an exploration of the ways in which this notion of autochtonie has succeeded (or not) in strengthening the foundations for grassroots movements in New Caledonia and French Polynesia in recent years, beyond occasional individual participation in UN forums.

\section{Fertile Ground? Indigenous Grassroots Movements in the French Territories of Oceania}

Since the Matignon Accords (I988), nickel mining has been central to economic development policies in New Caledonia. The agreement was aimed at an economic rebalancing of the three provinces, since the Northern and Island Provinces, peopled predominantly by Kanak, are underdeveloped in comparison to the Southern Province-the administrative and financial center under European control (Demmer 2007). Since 1990, the Northern Province, where Kanak representatives occupy the main elected positions, has become active in the industry and now controls a vast sector (Horowitz 2004).

At the beginning of the 2000s, a particular situation led to a vigorous affirmation of the "new Kanak strategy" (Demmer 2007), which used the framework of the international indigenous rights movement to articulate its demands. A new nickel refinery (first known as Goro Nickel and now called Vale Nouvelle-Calédonie), located near the capital city of Nouméa, planned to employ a new technology never used before in New Caledonia. This method uses "acid under pressure to leach nickel and cobalt from the 
ore" and is far more polluting (Horowitz 20I2, 8II). The project sparked concerns in the early 2000 s among local residents, local elected officials, and environmental organizations. One organization, the Kanak volunteer association Rhéébù Nùù-which means "eye of the country" (Horowitz 20I 2, 8I2)—was created in 2002 to represent the environmental and economic interests of the indigenous people of New Caledonia's Great South region. Over the years, with the help of a French lawyer specializing in indigenous rights, Jérôme Bouquet-Elkaïm, the self-identifying indigenous group put forward two main demands (in reference to the Draft Declaration on the Rights of Indigenous Peoples):

- environmental guarantees, in particular on the issue of the discharge of heavy metals in the lagoon;

- the creation of a heritage fund on the principle of free, prior and informed consent of indigenous peoples with regards to development projects that affect them. (Bouquet-Elkaïm 2006)

The Comité Autochtone de Gestion des Ressources Naturelles (CAUGern, Indigenous Committee for Natural Resources Management), a volunteer association created in 2005 that includes some of the leaders of Rhéébù Nùù, extended the indigenous action and demands to the whole county. They asked for legal long-term guarantees concerning Kanak asset management and ownership in the mining industry as well as financial compensation or royalties for the indigenous people (Demmer 2007).

Rhéébù Nùù succeeded in making many direct and indirect gains: in 2007, it caused the Administrative Tribunal to halt construction of the refinery until the company gave additional environmental guarantees. Rhéébù Nùù also signed, along with twenty-five customary authorities of the Great South and Goro Nickel representatives, the Pacte pour un Développement Durable du Grand Sud (the Pact for Sustainable Development of the Great South). Points in the pact include "creating a corporate foundation to fund local sustainable development initiatives, setting up a Consultative Customary Environmental Committee, ... recruiting and training local 'environmental technicians,' and implementing an extensive reforestation program" (Horowitz 20I2, 8I2). In addition, one of the organization's main leaders, Raphaël Mapou-a dissident FLNKs leader, kingpin of the indigenous movement-was named president of oeIL (The Eye), an environmental observatory created in 2009 (LNC 2009).

Collaborations, alliances, and support from outside sources played a 
strong role in the "new Kanak strategy" gaining legitimacy, facilitating negotiation with the mining company and the New Caledonian government and helping self-identified indigenous organizations to achieve some of their goals. The indigenous groups have succeeded in attracting international attention-mainly through local and international networking, press releases, demonstrations (including some violent actions at the Goro mining site that received media attention), the Internet, and travel overseas. The backing these groups received was not always straightforward; rather, it was linked to a multifaceted "game" of interests and influences (Horowitz 20I2). Supporters have included local and overseas environmental organizations; the Customary Senate; the New-Caledonian Green Party; the Union Syndicale des Travailleurs Kanaks et Exploités (UstKe, Trade Union of Kanak and Exploited Workers); the French Ligue Communiste Révolutionnaire (LCR, Revolutionary Communist League); prominent figures of the alter-globalization movement and of the Confédération Paysanne (Peasant Confederation, a French agricultural union) such as José Bové; indigenous peoples and "ordinary" citizens from around the world; and anthropologists and lawyers working on indigenous rights (Demmer 2007; Horowitz 20I2).

In French Polynesia, no particular event seems to have created the same kind of impetus toward a full-fledged social movement for "indigenous" demands. Instead, references to indigeneity and the affirmation of indigenous identity and rights were made by only a very small number of volunteer associations and were primarily motivated by cultural production (arts and literature, for example) and the preservation of cultural heritage.

Members of Littérama'ohi, a literary association created in 2002, have spoken of themselves as "indigenous writers." The association works to connect and promote writers from French Polynesia and publishes the journal Littérama'ohi. As of 2010, they have emphasized that their objective is to "promote the indigenous literature of French Polynesia" (Littérama'ohi 20I3). On I6 October 2010, for example, the group organized a debate entitled "Indigenous Peoples" during the book fair Lire en Polynésie française (Reading in French Polynesia). The following invitation was printed in the fair's program: "On I3 September 2007, the United Nations General Assembly adopted the Declaration on the Rights of Indigenous Peoples. Three years later, the indigeneity question concerning the indigenous peoples of French Polynesia has not yet been debated in our country. The Litterama'ohi Group proposes a moment of sharing about these themes." One of the organizers told me afterward, in May 
20II: "We expected that either people would come and attack us or would simply not come . . . and people did not come. . . . No, here, people do not recognize themselves as autochtones, do not want to be an indigenous people." In fact, only about fifteen people attended the event. The texts that were read that evening reviewed recent developments in the United Nations concerning indigenous peoples' rights; they were published a year later, in October 20II, along with a few other texts, in a special issue of Littérama'ohi titled Autochtonie et peuples autochtones (Indigeneity and Indigenous Peoples). Isidore Hiro's paper was an interesting addition to this special issue, illustrating the ambiguity of the notion of indigeneity for Mā‘ohi people.

Since then, the Littérama'ohi association has continued to use the term autochtone from time to time when speaking about their writings and activities-for example, in a public reading at the Papeete market in June 2OII (LNT 2OII). Why would they choose to do so? One reason is that it certainly tickles local people's curiosity and may therefore aid in promoting their work on the small French Polynesian book scene. It also allows the writers to show the relevance of their literature beyond French Polynesia by stressing a range of concerns shared by peoples around the globe. It seems to me that this strategy should be understood in light of recent increased contacts and collaborations with writers from around the Pacific region, as well as the development of new networks with selfidentifying indigenous peoples outside the area, notably through attending conferences. A particular bond has developed among these people.

Contacts and collaborations have been facilitated by the end of the nuclear era in French Polynesia. Participants in my research emphasized that regional opposition to "French nuclear colonialism" has had a strong effect on the indigenous populations of the French territories of Oceania, including on their travel and networking. In recent years, the effort that has gone into translation, the development of Internet and social networks (such as Facebook), and France's increasing openness to the English language has led to new contacts across the great divide between francophone and anglophone Oceania. As one example, Chantal Spitz's book L'Île des rêves écrasés (I99I), the "first ever novel by an indigenous Tahitian writer" (Huia website 2007), was translated into English as Island of Shattered Dreams in 2007 by Huia, a Māori publishing company. The Tahitian novelist has since been invited to several literary book fairs and conferences around the Pacific (in New Zealand, Australia, and Hawai $i$ i), along with other self-identifying indigenous writers. Members 
of Littérama'ohi were also invited to participate in an anthology of francophone indigenous writers (Gatti 2008), published in Montréal with the support of First Nations organizations. Some members also participated in a conference on emerging indigenous literatures that took place in the Huron-Wendat First Nation community of Wendake, near Québec city, in September 2008 (Gatti and Dorais 2010).

The following year, a delegation of Mā'ohi filmmakers, writers, and visual artists from the Centre des Métiers d'Arts (CMA, Center for the Arts), based in Papeete, participated in the nineteenth Montréal First Peoples' Festival / Festival Présence Autochtone. According to the CMA director, the trip to Montréal— the first trip overseas in the school's history-was a "mind-opener" to "indigenous commonalities," which encouraged them to organize a subsequent trip to New Zealand to meet Māori artists. The local media coverage of the event is a good illustration of people's lack of familiarity with indigenous issues and the word autochtone. For example, a reporter explained that the Festival Présence Autochtone was an "ethnic minorities festival" (Wong 2009) - a designation that shows misunderstanding and most probably a lack of awareness about the important distinction (which exists throughout the former British colonial empire) between First Nations peoples, the descendants of the first inhabitants who were colonized by the settler state, and ethnic minorities, who arrived later as immigrants.

This anecdote is illuminating in that it shows how the distinction is irrelevant within the French framework. The reporter's lack of awareness makes sense within the larger historical and political context of the French Republic, which, unlike Canada, has largely ignored indigenous reality as defined by the United Nations in its own territory. A fundamental point about the UN category "indigenous" is that it inherently contains claims for collective rights. In the French context, the difficulty with collective rights was evident in the French representative's ambiguous position during debates prior to the vote on the Declaration on the Rights of Indigenous Peoples by the Human Rights Council in 2006. France supported the declaration while knowing that, at the national level, it "would have legal difficulties" in terms of enforcement. The French representative argued that "since French law is based on the indivisibility of the Republic, the equality principle and its corollary, the principle of non-discrimination, collective rights cannot prevail over individual rights" (ОHCHR 2006). Trépied offered the following clarification: "Already in I99I, the French constitutional court, invoking the Republic's indivisibility, condemned 
the famous reference to the 'Corsican people, a component of the French people.' Similarly, the state only recognizes 'overseas populations' (see the constitutional revision of March 28, 2003) and, among them, 'indigenous populations' . . . older references to 'overseas peoples' included in the preamble to the 1946 constitution (relating [to] the French Union) and article one of the 1958 constitution (relating to the Communauté, a temporary union established between France and its former colonies) notwithstanding" (20I2b).

Another key problem with the UN category "indigenous" in the French constitutional framework is the fact that it considers the right of selfdetermination as meaning "indigenous autonomy" or "indigenous selfgovernment" (Henriksen 200I). In the context of the French Republic, these forms of power sharing based on the collective rights of a people within the community of French citizens have no precedent. Even in the case of New Caledonia, where an exception to the indivisibility of the French Republic already exists- "by virtue of the Nouméa Accord, which has been integrated into title XIII of the constitution (articles 76 and 77), the Republic officially recognizes the existence of a 'Kanak people' in New Caledonia" (Trépied 20I2b)—negotiations about power sharing take place between the French state and the local government, that is, New Caledonia as a whole.

As Trépied underlined (20I2b), however, the exception served the French government well when it was called to reply to the 20I I Report on the Situation of Kanak People in New Caledonia by James Anaya, UN special rapporteur on the rights of indigenous peoples. It was also to the benefit of the groups who rallied for their rights as autochtones, in particular in the conflicts around mining activities and environmental issues but also, more generally, in issues around the protection of cultural customs. By virtue of the Nouméa Accord, the French Republic specifically recognized "Kanak identity" and provided for the creation of the Customary Senate, which "must be consulted on subjects related to Kanak identity," as well as a specific regime of civil law-the customary civil status (a legacy of the colonial "particular civil status"; see Trépied 20I2b)—alongside the "ordinary" regime of civil rights. Over time, the Customary Senate has initiated a series of measures concerning the promotion of customary rights and has become the foundation of indigenous movements in New Caledonia, which have succeeded in making some significant gains (see, eg, Demmer 2007; Lafargue 20I0).

On this matter, French Polynesia's history differs from that of New Caledonia, since there is no such official recognition of Polynesian or Mā'ohi 
customs or of any kind of official "customary status" for the descendants of the indigenous people (for details, see Saura 200I). In addition to differences in timing, this could help shed light on why the major environmental concerns raised by nuclear testing in French Polynesia-in contrast with those provoked by the new mining project of the 2000 s in New Caledonia-have not worked as a catalyst for the formation of a strong indigenous movement. This could also explain the very limited success of people like Joinville Pomare (a descendant of the Pomare family, which reigned over Tahiti at the time when France took control of what is today French Polynesia), whose demands, inspired by the Kanak situation and discussions with Kanak leaders, have centered on customs and the reestablishment of customary institutions, as discussed later in this section.

In practice, however, there is one important exception. Although landownership falls under the French Civil Code, which formally prevents joint ownership by extended families, in practice the Mā'ohi traditional legal system still prevails in this area: 80 percent of the land outside urban zones is still collectively owned (Bambridge and Ghasarian 2002, I68-169). This situation-which has led to serious land problems-is the result of difficulty in implementing land registration. The land tenure question has been central to Joinville Pomare's campaign and to Tahiti-based associations under his leadership. These associations want land titles clarified and compensation procedures put in place for victims of land confiscations. They also ask that France respect "the treaties for the protectorate and annexation of $\mathrm{I} 842$ and I 880 , which guaranteed the protection of the royal family's land and land ownership for all Tahitians" (Saura 20I0, I7I). Pomare and his supporters have often couched their claims in a language that is somewhat foreign to the French "mould" but is widely used by indigenous peoples of the former British Empire (such as the Māori of New Zealand), with emphasis placed on respect for the foundational treaties that allowed the colonial takeover. This importance given to treaties has also been central to the work of Mareva Neti de Montluc who, as mentioned earlier, attended the UNPFII in New York in 2007, at which time she called on the French government to reexamine the validity of the "Treaty of I 880 " (UN 2007).

In 2005 , Joinville Pomare announced the creation of a traditional royal council, putting forward a proposal in Paris for a local senate based on local customs. He was inspired in part by the Kanak Customary Senate, "which would be given the task of offering to be an arbitrator or mediator in land disputes and of giving its opinion in the elaboration of the rules of laws" (quoted in Saura 2008, 446). In 2006, he founded the chieftainship 
of Teva i Tai and appointed judges for the great chieftainships of Tahiti and the archipelagos. In 2007, he was behind the assembly of the "monarchs" of what is known as the Polynesian triangle to restore ancestral links and draw attention to France's non-respect of its commitments on matters relating to lands on the marae (ceremonial center) Taputapuātea. Māori and Cook Islands representatives attended the assembly (Tahiti Presse 2007). In 2009, a great investiture ceremony was announced during which Joinville Pomare was to be named Pomare XI (Saura 20I0). This announcement was met with opposition from many members of his family who question his claim to the throne and from several associations that favor democratic legitimacy-beginning with the ballot box. In general, the Mā'ohi are largely against the restoration of hereditary monarchy or chiefdoms, as I heard numerous times during my fieldwork. This opposition finally prevented the ceremony from being held. The road has thus been strewn with obstacles for Joinville Pomare and the associations that support him. Nonetheless, at the beginning of $20 \mathrm{I}_{5}$, they reiterated their intention of taking control of their own destiny, in particular in helping Polynesians to regain their lands, through the creation of an indigenous customary senate called Pare Mata, which in Tahitian means "The Lighthouse" (LTD 20I5).

I should mention that Pomare, like some Kanak leaders (Raphaël Mapou, for instance, who was at the forefront of Rhéébù Nùù's action), has long been involved in traditional party politics and positioned himself as an independentist in the long-standing opposition described in the introduction to this article. He has, however, remained a rather marginal player in the traditional political field. The exploration of the new "indigenous strategy" might have been an avenue for him (and other leaders) to make a difference. In 2009, Pomare renewed his engagement with party politics and the electoral process, becoming leader of the new Parti Indigène Anoanotupu, a native-rights political party that only existed for a few months. Note that, in contrast, in New Caledonia the previous year, the self-identified indigenous association Rhéébù Nùù presented candidates at the 2008 municipal elections in the southern municipality of Yaté. In 2009, foreseeing the provincial elections, the group created the Collectif Autochtone pour une Liste Unitaire en Province Sud (Indigenous Collective for a Unitary Roll in the Southern Province), but by the end of the electoral campaign it finally gave its support to the FLNKS.

It seems to me that the particularities of local and French contexts discussed thus far could also, perhaps, shed light on the cautious and often 
ambiguous stance of Richard Tuheiava and his use of the "indigenous strategy." At the end of $20 \mathrm{II}$, Tuheiava (a Polynesian and member of the French Senate) published a book of interviews with journalist Serge Massau, with the provocative title Paroles d'un autochtone (In the Words of an Indigenous Man; 20II). In this book, Tuheiava discussed his views on decolonization (among other things) and insisted on the necessity of taking into account the particularities of Polynesian culture-the indigenous culture. These include Polynesian values of hospitality and solidarity as well as the ancestral obligations and responsibilities attached to them, particularly with respect to environmental and heritage preservation. Some passages related to indigeneity are illustrative. Speaking of his childhood, Tuheiava said: "Looking back, my older brother and I had the privilege of benefiting, on one hand, thanks to my father, from a strict education centered on the language and the culture, therefore on indigeneity [autochtonie in the original], and, on the other hand, from the learning of worldliness, thanks to my mother, who has English blood and an outstanding flair for human relations" (Massau 20I I, 25).

When asked about Marae Taputapuātea, which he described as "a center for Polynesian-ness, a center for indigeneity," he said: "For me, this site represents the archetype of how we have shaped our cosmology, how a whole people have gathered around the values, the rules ... how a whole people have united around a vision of the universe at a given time.... this type of site draws on concepts that are far from Western ones" (Massau 20I I, 44-45).

In Tuheiava's book of interviews, references to indigeneity and indigenous rights are primarily, if not uniquely, about the promotion, preservation, and sustainability of his people's cultural specificities and worldviews. It is important to mention that, under his leadership, Marae Taputapuātea has appeared since 2010 on the tentative list of "properties" that France considers suitable for registration on the UNESCO World Heritage List. In 20I2, Tuheiava also coauthored an article in UNESCO's journal World Heritage, alongside two Māori representatives (Te Heuheu, Kawharu, and Tuheiava 20I2). The article is the introduction to a special issue entitled World Heritage and Indigenous Peoples "devoted to the enduring relationship between a number of World Heritage sites and the indigenous peoples that inhabit them" (World Heritage 201 2, 3 ). The essay discusses the concept of "indigeneity" and the new possibilities it offers in terms of identification, management, and preservation of world heritage. 
When it comes to issues of "real power," however-that is, decolonization and sovereignty-Tuheiava, as we've seen, does not appeal to the UN Declaration on the Rights of Indigenous Peoples; nor has he, to my knowledge, participated in the UNPFII. Instead, he makes himself heard at the UN Special Committee on Decolonization. After all, as emphasized by Roger Maaka and Augie Fleras, "Indigenous politics are animated by a logic to de-colonise from 'within'" $(2005,4 \mathrm{I})$-they are about internal aspects of the right to self-determination.

\section{Conclusion}

Although the word autochtones (indigenous) is used more frequently today among Mā'ohi and Kanak people, and the "indigenous strategy" has made some gains in specific circumstances, most self-identified indigenous groups and indigenous claims or discourses are still situated in the margins of the political arena. In New Caledonia, however, this is less and less the case: there, the Nouméa Accord and its implementation since 1998 have paved the road for indigenous politics. While this article demonstrates the benefits that the indigenous strategy could have, it also shows that it can be a source of discomfort. This echoes an idea that Marie Salaün and I put forward previously: "any discussion of indigeneity and the way that people represent themselves as indigenous must be analyzed with a strong focus on social and political contexts" (Gagné and Salaün 20I 2, 389). This also illustrates that those who still "believe that one's political genesis begins with one's biological history" (Hokowhitu 20I3, 362) are proven to be wrong. Indigeneity is largely relational and finds its way (or doesn't) into specific contexts of struggle. As I have tried to show here through the exploration of specific examples, the framework for the struggles of the indigenous peoples of the French territories in Oceania differs radically from those of other groups who have been seen as emblematic of the category "indigenous peoples," such as the Amerindians, the Māori of New Zealand, and the Aborigines of Australia. Specifically, this framework is characterized by the particularities of French national political history and by the demographic weight of indigenous populations in the territories concerned. Specific contexts of struggle have profound repercussions. I believe that one of the strengths of anthropology is found precisely in its ability to shed light on the practical implications of the kinds of circumstances that guide people in their selfidentification and choice of political strategy. 
THE RESEARCH that led to this article was facilitated by a research grant from the Social Sciences and Humanities Research Council of Canada. I thank all the research participants who so generously shared their time with me for discussions and interviews. I am grateful to Marie Salaün and Benoît Trépied, whose suggestions have been helpful in developing this article. I would also like to thank the journal's anonymous reviewers, as well as Bruno Saura for his invitation to participate in this special issue.

\section{Notes}

I Some anthropologists have also voiced strong opposition to indigenous politics (among others, Geschiere 2009; Kelly and Kaplan 200I; Amselle 2010). In both cases, the positioning is often ideological and preempts a detailed empirical analysis of contemporary appeals to indigeneity—or its refusal—on the ground and in particular contexts.

2 An important distinction exists between the two meanings of "indigeneity": one denotes a universal category based on ancient usage; the other-which is the subject of this article-is a specific term referring to a political and identity category as well as a legal category defined under international law, largely under UN supervision, since the end of the I970s. No matter what language it is expressed in, the "universal" concept of "indigeneity" has been used throughout history to mark the difference between those who originate from "here" and those who came from "elsewhere"-immigrants. The distinction has a long history in Oceania, including among Mā'ohi and Kanak people (see, eg, Bensa 2009; Sahlins I985; Saura 2004, 2008).

3 All translations of excerpts from interviews and written documents from the French are my own. Pseudonyms are used to identify research participants.

4 The Établissements Français de l'Océanie (the former name of French Polynesia) were put on the UN list for the first time in 1946, along with New Caledonia, but both territories were removed from the list in 1947 under pressure from the French government.

5 For a summary of what happened in the months leading up to and following the General Assembly's resolution, through 3 I May 20I3, see Maclellan 20I3.

6 This category was completely new in the 2009 census (see Muckle and Trépied 20I4).

7 For an English summary of the content of the Nouméa Accord, see Maclellan I999. In I988, the Matignon Accords provided a ten-year transition period with a referendum on self-determination scheduled before the end of I998. A negotiation finally led to the Nouméa Accord, which postponed the referendum for at least fifteen years. 
8 This percentage comes from the I988 census, the last census to measure ethnic identity. According to this census, about I 2 percent of the population is of European origin and about 5 percent is Asian, mainly of Chinese origin.

9 Flosse was president of French Polynesia from I982 to I987, from I991 to 2004, for a few months between October 2004 and March 2005, and again from 23 February 2008 to I5 April 2008 (see EPF 20I3). He was reelected in May 2013 and then removed from office as French Polynesia's president in September 2OI4 for a conviction of corruption. He was also removed from his seat in the French Senate.

Io For historic reasons, autochtone is the preferred term in French since the word indigène is directly associated with the legal status assigned to the subjects-in contrast with the citizens-of the French colonial empire. For a discussion on the uses by various actors in local, national, and international contexts of the two distinct yet closely interrelated concepts of "indigeneity" and "autochthony," in particular in relation to Africa, see Pelican 2009 and Gausset, Kenrick, and Gibb 20II.

I I This is very striking in the French social sciences. A decade ago, there was nothing resembling a research field called "indigenous studies," even though researchers have been doing research among indigenous populations of the Americas, Africa, and Oceania for a long time. Those who had looked specifically at the UN initiatives and who framed their research around the concepts of peuples autochtones (indigenous peoples) and autochtonie (indigeneity) were exceptions (on this situation, see Gagné and Salaün 2009). Since then, however, research initiatives around those concepts have multiplied.

I 2 The first session was held in May $200 \mathrm{I}$.

I 3 "Hiti Tau literally means 'Stand up and make a change.' . . Its mission was to bring together the indigenous Maohi people in their struggle for the recognition of their universal rights, sustainable development and the right to a nonnuclear homeland" (Peace Boat 2005).

I4 Françoise Morin and Bernard Saladin d'Anglure, pers comm, Sept 2013. See also Morin 2008.

I 5 An analysis of the local media coverage of the event that I conducted confirmed this statement.

I 6 Note that in recent years, the extreme right in metropolitan France has used the term autochtones in an entirely different sense to express anti-immigration positions, distinguishing two classes of citizens: those who are of French (ethnic) origin-the autochtones - and those who are not. This infringes on the French Republican principle of equality of citizens.

I 7 In French Polynesia, questions pop up from time to time concerning the delicate situation of the Chinese minority and whether they could be considered autochtones natifs or autochtones de souche considering their long and at times painful history in French Polynesia. Similar questions have arisen in New Caledonia concerning other minority populations. 


\section{References}

Al Wardi, Sémir

2009 Twenty Years of Politics in French Polynesia. Journal of Pacific History 44:195-208.

2010 Le Mouvement indépendantiste en Polynésie française de I 946 à nos jours. In Visages de la souveraineté dans le Pacifique, edited by Natacha Gagné and Marie Salaün, I39-I 58. Paris: L'Harmattan.

Amselle, Jean-Loup

2010 Rétrovolutions: Essais sur les primitivismes contemporains. Paris: Stock.

Bambridge, Tamatoa, and Christian Ghasarian

2002 Juridictions françaises et droit coutumier à Rapa: Les enjeux d'une traduction. Droit et Cultures 44:I 53-I 82.

Bellier, Irène

2003 Dernières nouvelles du Groupe de travail de l'ONU sur le projet de déclaration des droits des peuples autochtones. Recherches Amérindiennes au Québec 33 (3): 93-99.

Bensa, Alban

2009 Usages savants et politiques de la notion d'autochtonie. In Autochtonies: Vues de France et $d u$ Québec, edited by Natacha Gagné, Thibault Martin, and Marie Salaün, 2I-32. Québec: Presses de l'Université Laval.

Bouquet-Elkaïm, Jérôme

2006 Invitation à la conciliation devant cour permanente d'arbitrage. Rhéébù Nùù website: http://www.rheebunuu.com/doc/2006042I _arbitrage.doc [accessed 23 Aug 2006; site discontinued]

Chappell, David A

2007 Melanesia in Review: Issues and Events, 2006: New Caledonia. The Contemporary Pacific I 9:582-597.

Demmer, Christine

2007 Autochtonie, nickel et environnement: Une nouvelle stratégie kanake. Vacarme 39:43-48.

EPF, État en Polynésie française

20I3 Le Président de la Polynésie française. Haut-Commissariat de la République française en Polynésie française. http://www.polynesie -francaise.pref.gouv.fr/Les-elus/Le-President [accessed 3 I Oct 20I3]

FD, France Diplomatie

20I3 Résolution adoptée par l'Assemblée générale des Nations unies sur la Polynésie française (I7 mai 20I3). Ministère des Affaires étrangères, République française. http://www.diplomatie.gouv.fr/fr/politique -etrangere-de-la-france/onu/evenements-et-actualites-lies-aux/ 
actualites-2 I 429/article/resolution-adoptee-par-l-assemblee [accessed 3I Oct 2013]

Gagné, Natacha

20 I La Stratégie autochtone: Ses trajectoires en Océanie. In Destins des collectivités politiques d'Océanie, vol I: Théories et pratiques, edited by Viviane Fayaud, Jean-Yves Faberon, and Jean-Marc Regnault, 263-272. Aix-en-Provence: Presses Universitaires d'Aix-Marseille.

2012 Indigenous Peoples, A Category in Development. In Introduction to International Development Studies: Approaches, Actors, and Issues, edited by Paul Haslam, Jessica Schafer, and Pierre Beaudet, 454-472. 2nd edition. Oxford: Oxford University Press.

Gagné, Natacha, and Marie Salaün

2009 Présentation. In Autochtonies: Vues de France et du Québec, edited by Natacha Gagné, Thibault Martin, and Marie Salaün, xiii-xx. Québec: Presses de l'Université Laval.

2012 Appeals to Indigeneity: Insights from Oceania. Social Identities I $8: 38$ I-398.

Garot, Pierre-Emmanuel

2013 44ème Forum du Pacifique: Flosse défend l'autonomie et critique Temaru. Polynésie ıère, 4 September. http://polynesie.laıere.fr/ 2013/o9/04/44eme-forum-du-pacifique-flosse-defend-l-autonomie -et-critique-temaru-66897.html [accessed 3 I Oct 20I3]

Gatti, Maurizio, editor

2008 Mots de neige, de sable et d'océan: Littératures autochtones (Québec, Maroc, Polynésie française, Nouvelle-Calédonie, Algérie). Wendake, QC: Les Éditions du CDFM.

Gatti, Maurizio, and Louis-Jacques Dorais, editors

2010 Littératures autochtones. Montréal: Mémoire d’Encrier.

Gausset, Quentin, Justin Kenrick, and Robert Gibb

20II Indigeneity and Autochthony: A Couple of False Twins? Social Anthropology/Anthropologie sociale I9 (2): I35-I42.

Geschiere, Peter

2009 Perils of Belonging: Autochthony, Citizenship, and Exclusion in Africa and Europe. Chicago: University of Chicago Press.

GITPA, Groupe International de Travail pour les Peuples Autochtones

2009 La Coordination Autochtone Francophone. http://gitpa.org/ Processus\% 20Frame.htm [accessed 3I Oct 20I3]

Gonschor, Lorenz

2013 Mai te hau Roma ra te huru: The Illusion of "Autonomy" and the Ongoing Struggle for Decolonization in French Polynesia. The Contemporary Pacific 25:259-296. 
Graff, Stéphanie

20I2 Quand combat et revendication kanak ou politique de l'État français manient indépendance, décolonisation, autodétermination et autochtonie en Nouvelle Calédonie. Journal de la Société des Océanistes $\mathrm{I} 34: 6 \mathrm{I}-83$.

Henriksen, John B

200I Implementation of the Right of Self-Determination of Indigenous Peoples. Indigenous Affairs 3:6-2I.

Hiro, Isidore

20I I Autochtone suivi de Ta'ata Tumu. Littérama'ohi I9:37-4I.

Hiti Tau

I995 Declaration given during the Working Group on Indigenous Peoples in the United Nations Organization in Geneva on 27 July I995. Unrepresented Nations and Peoples Organization's website: http:// www.unpo.org/article/I $367 \#$ sthash.2CgwE4gw.dpuf [accessed $3 \mathrm{I}$ Oct 20I3]

Hokowhitu, Brendan

20I3 Producing Indigeneity. In Indigenous in the City: Contemporary Identities and Cultural Innovation, edited by Evelyn Peters and Chris Andersen, 354-376. Vancouver: UBC Press.

Horowitz, Leah S

2004 Toward a Viable Independence? The Koniambo Project and the Political Economy of Mining in New Caledonia. The Contemporary Pacific I 6:287-3 I9.

2009 Environmental Violence and Crises of Legitimacy in New Caledonia. Political Geography 28:248-258.

20I0 Twenty Years Is Yesterday: Science, Multinational Mining, and the Political Ecology of Trust in New Caledonia. Geoforum 4I:6I 7-626.

20I2 Translation Alignment: Actor-Network Theory, Resistance, and the Power Dynamics of Alliance in New Caledonia. Antipode 44:806827.

Huia website

2007 Island of Shattered Dreams by Chantal Spitz. http://www.huia.co.nz/ shop\&item_id=4384 [accessed 3 I Oct 20I3]

ISEE, Institut de la Statistique et des Études Économiques, Nouvelle-Calédonie

2009 4-Population. Recensement de la population. http://www.isee.nc/ tec/popsociete/telechargements/4-population.pdf [accessed 3 I Oct 2OI3]

Kelly, John D, and Martha Kaplan

200I Represented Communities: Fiji and World Decolonization. Chicago: University of Chicago Press. 
Lafargue, Régis

20 Iо La Coutume face à son destin: Réflexions sur la coutume judiciaire en Nouvelle-Calédonie et la résilience des ordres juridiques infraétatiques. Paris: LGDJ.

LDT, La dépêche de Tahiti

2013 On s'est regardé le pito sans voir qu'un jour ou l'autre, d'autres pays allaient être compétitifs. 2I March.

2015 Joinville Pomare veut mettre en place un sénat coutumier. 27 February.

Littérama'ohi

2013 Littérama'ohi’s Facebook page. https://www.facebook.com/pages/ Littéramāohi/I 4958543 I 755454 !/pages/Littéramāohi/ I4958543I755454 [accessed 3 I Oct 20I3]

LNC, Les Nouvelles Calédoniennes

2009 Un “œil” pour surveiller l'usine du Sud. 4 March.

LNT, Les Nouvelles de Tahiti

20I I Lecture publique Littérama'ohi au marché de Papeete. 30 June.

Maaka, Roger, and Augie Fleras

2005 The Politics of Indigeneity: Challenging the State in Canada and Aotearoa New Zealand. Dunedin: University of Otago Press.

Maclellan, Nic

2013 "Hijacking Decolonisation": French Polynesia at the United Nations. Institute for Social Research. http://inside.org.au/highjacking -decolonisation-french-polynesia-at-the-united-nations/ [accessed $3 \mathrm{I}$ Oct 20I3]

Massau, Serge

20I I Paroles d'un autochtone: Entretiens avec le sénateur Richard Ari'ihau Tuheiava. Papeete: Haere Pō.

Merle, Isabelle

2004 De la légalisation de la violence en contexte colonial: Le Régime de

Minde, Henry l'indigénat en question. Politix 66:137-162.

I996 The Making of an International Movement of Indigenous Peoples. Scandinavian Journal of History 21:22 I-246.

Mohamed-Gaillard, Sarah

2008 Parcours de l'indépendance kanak de la Nouvelle-Calédonie aux Nations unies. In Annales d'Histoire Calédonienne, vol 2, edited by Eddy Wadrawane and Frédéric Angleviel, 349-364. Paris: Les Indes Savantes.

Monnerie, Denis

2005 La Parole de notre maison: Discours et cérémonies kanak aujourd'hui 
(Nouvelle-Calédonie). Paris: CNRs Éditions and Éditions de la Maison des Sciences de l'Homme.

Morin, Françoise

2008 La Participation des autochtones francophones à l'ONU. Des Peuples autochtones en mouvement. http://www.peuplesautochtonesfrancophones.reseaudialog.ca/Caf_ONU.html [accessed 3 I Oct 20I3]

2009 L'Autochtonie comme processus d'ethnogenèse. In Autochtonies: Vues de France et du Québec, edited by Natacha Gagné, Thibault Martin, and Marie Salaün, 59-73. Québec: Presses de l'Université Laval.

Muckle, Adrian

2012 The Presumption of Indigeneity: Colonial Administration, the "Community of Race" and the Category of Indigène in New Caledonia, I 887-I946. Journal of Pacific History 47 (3): 309-328.

Muckle, Adrian, and Benoît Trépied

20I4 Les Transformations de la "question métisse" en Nouvelle-Calédo-

Niezen, Ronald nie (1853-2009). Anthropologie et sociétés 38 (2): 89-108.

2003 The Origins of Indigenism: Human Rights and the Politics of Identity. Berkeley: University of California Press.

OHCHR, Haut-commissariat aux Droits de l'Homme (Office of the High Commissioner for Human Rights)

2006 Projet de déclaration sur les droits des peuples autochtones. http:// www.unhchr.ch/huricane/huricane.nsf/viewor/BCE2 I 5 Co I 8CE43 84CI257I9A0070 55 F7 ?opendocument [accessed I Aug 20II; site discontinued]

Peace Boat website

2005 Port of Call. 5 January. http://www.peaceboat.org/english/voyg/47/ poc/papeete/ [accessed 3 I Oct 20I3]

2008 Life Onboard. 2 April. http://www.peaceboat.org/english/voyg/6o/

Pelican, Michaela lob/o80402/index.html [accessed 3I Oct 20I3]

2009 Complexities of Indigeneity and Autochthony: An African Example. American Ethnologist 36:52-65.

Raapoto, Duro

I978 Maòhi, ou l'identité bafouée. Journal des Missions Évangéliques 7-89:II4-II9.

Regnault, Jean-Marc

$20 \mathrm{I} 3$ L'ONU, la France et les décolonisations tardives: L'Exemple des terres françaises d'Océanie. Aix-en-Provence: Presses Universitaires d'Aix-Marseille. 
Sahlins, Marshall

I98 5 Islands of History. Chicago: University of Chicago Press. Saura, Bruno

200I Customary Rules in French Polynesia. In Custom and the Law, edited by Paul de Deckker and Jean-Yves Faberon, 8I-II7. Canberra: Asia Pacific Press.

2004 Dire l'autochtonie à Tahiti. Journal de la Société des Océanistes I I9:I I9-I37.

2008 Tahiti Mā'ohi: Culture, identité, religion et nationalisme en Polynésie française. Papeete: Au Vent des Îles.

2010 Le Mouvement royaliste et coutumier contemporain en Polynésie française: De l'étranger-roi à l'autochtone souverain? In Visages de la souveraineté dans le Pacifique, edited by Natacha Gagné and Marie Salaün, I 59-183. Paris: L'Harmattan.

Soriano, Eric

200I Une trajectoire du politique en Mélanésie: Construction identitaire et formation d'un personnel politique; L'Exemple kanak de Nouvelle-

Spitz, Chantal T

Calédonie (I946-I999). PhD dissertation, Université Montpellier I.

I99I L'Île des rêves écrasés. Papeete: Les Éditions de la Plage.

2007 Island of Shattered Dreams. Wellington: Huia.

2OII Sommes-nous prêts à hériter de notre autochtonie? Littérama'ohi I 9:94-98.

Stoler, Ann Laura

20I I Colonial Aphasia: Race and Disabled Histories in France. Public Culture 23:I 2I-I 56.

Tahiti Infos

20I3 Isidore Hiro, Mo'orea sa terre nourricière, et le trésor de Patii. Io July. http://www.tahiti-infos.com/ISIDORE-HIRO-Mo-orea-sa -terre-nourriciere-et-le-tresor-de-Patii_a 78 545.html [accessed 3 I Oct 2OI3]

Tahiti Presse

2007 Familles royales: Vers une union élargie aux Mélanésiens et Micronésiens. I3 November. http://www.tahitipresse.pf/index.cfm?snav =see \&presse=22 I07 [accessed I4 Nov 2007; site discontinued]

Te Heuheu, Tumu, Merata Kawharu, and Richard Ariihau Tuheiava 2012 World Heritage and Indigeneity. World Heritage 62:8-I7.

Trémon, Anne-Christine

2006 Conflicting Autonomist and Independentist Logics in French Polynesia. Journal of the Polynesian Society I I 5:259-288.

2013 Citoyens indigènes et sujets électeurs: Statut, race et politique dans 
les Établissements français de l'Océanie (I880-I945). Genèses

Trépied, Benoît 9I: $28-48$.

20I2a Indigenous Struggles and Water Policies in New Caledonia. Social Identities I 8:465-479.

20I2b A New Indigenous Question in France's Overseas Territories? Books \& Ideas.net, I3 June. http://www.booksandideas.net/A-New -Indigenous-Question-in.html [accessed 3 I Oct 20I3]

20I3 Chefferie, bétail et politique: Un notable kanak contre la revendication d'indépendance en Nouvelle-Calédonie. Anthropologica 55 (2): $335-348$.

Trépied, Benoît, and Stéphanie Guyon, editors

20I3 Outre-mer indigènes. Genèses 9I.

UN, United Nations

2007 Sixth session of the UNPFII, I4-25 May. http://undesadspd.org/ IndigenousPeoples/UNPFIISessions/PreviousSessions/Sixth.aspx [accessed I Dec 20I4]

2008 Seventh session of the UNPFII, 2I April-2 May. http://undesadspd .org/IndigenousPeoples/UNPFIISessions/Seventh.aspx [accessed I Dec 20I4]

20I0 Ninth session of the UNPFII, I9-30 April. http://undesadspd.org/ IndigenousPeoples/UNPFIISessions/Ninth.aspx [accessed I Dec 2OI4]

Weil, Patrick

2008 How to be French: Nationality in the Making since I789. Translated by Catherine Porter. Durham, NC: Duke University Press.

Wong, Jennyfer

2009 Présence autochtones à Montréal. Les Nouvelles de Tahiti, I 2 June. World Heritage

20I2 World Heritage and Indigenous Peoples. Special issue, February. Paris: Unesco Publishing.

\section{Abstract}

In French Polynesia and New Caledonia, the "indigenous strategy" in reference to the world indigenous movement and UN indigenous rights instruments is a relatively new one in the struggle to recover sovereignty. Individuals and volunteer associations only began to explore the possibilities of this strategy in the midI990s, and it continues to hold a marginal place in the political field of the French 
territories in Oceania. This article explores how indigeneity and indigenous rights are understood and enacted locally, drawing on local voices and actions within a local and national context. It shows how the framework for the struggles of the indigenous peoples in the French territories in Oceania differs radically from those of other peoples who have been seen as emblematic of the category "indigenous peoples.”

KEYWORds: French Polynesia, New Caledonia, indigenous peoples, indigeneity, decolonization, sovereignty, political strategy 